\title{
Retention of dormant copepods in deep basins of the Southern California Bight
}

\author{
Catherine L. Johnson* \\ Integrative Oceanography Division, Scripps Institution of Oceanography, 9500 Gilman Drive, La Jolla, \\ California 92093-0218, USA \\ Present address: Ocean Process Analysis Laboratory, University of New Hampshire, 142 Morse Hall, Durham, \\ New Hampshire 03824-3525, USA
}

\begin{abstract}
The vertical distribution and abundance of dormant Calanus pacificus were described in deep basins and at deep, non-basin locations in waters off Southern California in October 1999 and 2000 and January 1999. Dormant C. pacificus were present in deep water at all stations sampled. In each month, vertical distributions were similar across the region sampled. The abundance of dormant C. pacificus was higher and their depth range was broader and deeper in October than in January. There was no difference in the abundance of dormant C. pacificus in basins and at deep, non-basin locations in October. Except for the Santa Barbara Basin, Southern California Bight basins were too deep relative to the vertical distribution of dormant C. pacificus to trap dormant copepods. Migration to deep water during dormancy in this region removes copepods from equatorward flow in surface waters. Dormant copepods are exposed either to poleward flow at the shallow end of their depth range in the continental borderlands of Southern California, or to very low current velocities in deeper water, both at basin and non-basin locations. The broad horizontal distribution of dormant C. pacificus in this region implies that non-point sources are dominant in re-seeding surface waters at the end of the dormant season.
\end{abstract}

KEY WORDS: Calanus pacificus $\cdot$ California Current $\cdot$ Copepod $\cdot$ Diapause $\cdot$ Dormancy $\cdot$ Retention Resale or republication not permitted without written consent of the publisher

\section{INTRODUCTION}

The life cycle of the dominant California Current copepod species Calanus pacificus includes a period of dormancy and descent to deep water that allows copepods to escape from seasonally unfavorable conditions at the surface (Alldredge et al. 1984, Osgood \& Frost 1994, Dahms 1995, Osgood \& Checkley 1997a,b, Ohman et al. 1998). Dormancy is a state of suppressed development, often occurring in the fifth copepodid (C5) stage of development in oceanic copepods and associated with cessation of feeding, reduced metabolic rates, high lipid reserves, resistance to anaerobiosis, and inactivity (Hirche 1996). In eastern boundary current systems, as in other ocean regions where surface advection is strong, transport out of productive regions may have a significant influence on copepod populations (Peterson 1998). Descent to deep water during dormancy can alter the flow regime to which copepods are exposed and influence horizontal transport, potentially increasing retention in favorable regions (Eiane et al. 1998).

Copepod transport and retention during dormancy can be influenced by bathymetry, for example when copepods migrate below the sill depth of continental shelf basins or fjords (Sameoto \& Herman 1990, Osgood \& Frost 1996). Basins and fjords, where deep water is bathymetrically isolated and mean current velocities are near zero, may act to aggregate and retain dormant copepods, if copepods descend from water advected over the basin (Sameoto \& Herman 1990, Osgood \& Checkley 1997b, Bagøien et al. 2000). High concentrations of dormant C5s in the Santa Barbara Basin, at the northern end of the Southern Cali- 


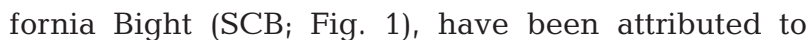
retention of individuals advected over the basin during the onset of dormancy and migration to deep water (Alldredge et al. 1984, Osgood \& Checkley 1997a,b). These locations may serve as point sources of copepods seeding surface waters when they emerge from dormancy. Alternatively, descent to deep water in areas where subsurface flow is in opposition to surface flow, such as poleward undercurrents in eastern boundary current systems, may transport copepods back to productive regions (Fleminger 1966, John et al. 1998, Peterson 1998, Johnson \& Checkley 2004). This process may serve as a non-point source of individuals reseeding surface waters at the end of the dormant period. Dormant Calanus pacificus may be influenced both by retention in basins and transport in the undercurrent. High concentrations of dormant C. pacificus have been observed in the Santa Barbara Basin (Alldredge et al. 1984, Osgood \& Checkley 1997a,b). Lower concentrations have been observed in the water column outside of basins, at the depth of the undercurrent, and in deeper water (Longhurst 1967, Ohman et al. 1998, Johnson \& Checkley 2004).

The SCB (Fig. 1) is a bathymetrically complex region of basins and ridges bounded by the coast from Point



Fig. 1. Southern California Bight and station locations (+: MOCNESS starting locations; AP: Anacapa Passage; SD: San Diego; SRC: Santa Rosa-Cortez Ridge). Depths are in meters. Basins sampled were Santa Barbara Basin (SBB), Santa Monica Basin (SMB), Santa Cruz Basin (SCrB), San Nicholas Basin (SNB), Santa Catalina Basin (SCaB), and San Clemente Basin (SCl). Open water stations sampled included San Diego Trough (SDT) and numbered California Cooperative Oceanic Fisheries Investigations (CalCOFI) stations. Un-sampled basins in the region shown are East Cortez Basin (EB), Long Basin (L), San Pedro Basin (SPB), Tanner Basin (T), and West Cortez Basin (WC)
Conception, USA, to Cabo Colnett, Baja California, Mexico, and by the Santa Rosa-Cortez Ridge to the west. Seven of the submarine basins in the SCB, including the Santa Barbara Basin, are north of the United States-Mexico border (Emery 1960). The California Undercurrent, which is warmer, saltier, and lower in oxygen than the equatorward California Current, flows poleward along the continental slope into the SCB. California Undercurrent flow is influenced by the complex bathymetry of the SCB, which steers the core of the undercurrent westward to the south of the Channel Islands and other branches through gaps in the Santa-Rosa-Cortez Ridge and through the Anacapa Passage (Lynn \& Simpson 1990).

The objective of the present study was to determine whether dormant copepods are aggregated and retained in basins of the SCB. The distribution and abundance of Calanus pacificus C5s emerging from dormancy, as well as the timing of emergence, set initial conditions for population growth of open-ocean copepods during favorable periods. If basins aggregate and retain dormant copepods, then these locans could serve as point sources of copepods seeding surface waters when they emerge from dormancy. Thus, interactions between dormancy behavior and local bathymetry could impose spatial structure on the initial conditions for population growth. Understanding these interactions is essential to modeling cope- pod population dynamics and predicting their response to climate variability.

\section{MATERIALS AND METHODS}

Vertically stratified zooplankton samples were collected at 10 stations in October 1999 and 2000 and at 13 stations in January 1999 (Table 1, Fig. 1), as seasonally maximal abundances of dormant Calanus pacificus had been observed in October or November (Osgood \& Checkley 1997b, Johnson \& Checkley 2004). Samples were collected using a $1 \mathrm{~m}^{2}, 10$ net MOCNESS, equipped with $333 \mu \mathrm{m}$ mesh nets and pressure, conductivity, temperature, and dissolved oxygen sensors. Sampling was performed during California Cooperative Oceanic Fisheries Investigations (CalCOFI) quarterly monitoring cruises, and tows were performed as stations were encountered (for times, see Table 1). Basins chosen for sam- 
Table 1. Sampling dates and positions (in degrees and minutes). Numerical station designations are in CalCOFI format (i.e. line number.station number). Starting positions of stations marked with an asterisk deviated from the CalCOFI station position

\begin{tabular}{|c|c|c|c|c|}
\hline Station & Date & Time-start (h) & Lat. (N) & Long. (W) \\
\hline Santa Barbara Basin & 28 Jan 1999 & $02: 20$ & $34^{\circ} 16.1^{\prime}$ & $119^{\circ} 59.3^{\prime}$ \\
\hline Santa Monica Basin & 16 Jan 1999 & $21: 16$ & $33^{\circ} 41.6^{\prime}$ & $118^{\circ} 52.5^{\prime}$ \\
\hline San Pedro Basin & 15 Jan 1999 & $22: 36$ & $33^{\circ} 29.8^{\prime}$ & $118^{\circ} 17.5^{\prime}$ \\
\hline Santa Catalina Basin & 15 Jan 1999 & 06:06 & $33^{\circ} 09.2^{\prime}$ & $118^{\circ} 34.5^{\prime}$ \\
\hline Santa Cruz Basin & 28 Jan 1999 & $19: 31$ & $33^{\circ} 42.1^{\prime}$ & $199^{\circ} 30.1^{\prime}$ \\
\hline San Nicolas Basin & 14 Jan 1999 & $22: 40$ & $33^{\circ} 05.4^{\prime}$ & $119^{\circ} 01.9^{\prime}$ \\
\hline San Clemente Basin & 29 Jan 1999 & $09: 37$ & $32^{\circ} 29.1^{\prime}$ & $118^{\circ} 05.1^{\prime}$ \\
\hline 70.60 & 27 Jan 1999 & $04: 40$ & $35^{\circ} 53.2^{\prime}$ & $122^{\circ} 21.9^{\prime}$ \\
\hline 77.55 & 24 Jan 1999 & $16: 03$ & $34^{\circ} 54.0^{\prime}$ & $121^{\circ} 13.2^{\prime}$ \\
\hline 80.60 & 27 Jan 1999 & $17: 48$ & $34^{\circ} 09.1^{\prime}$ & $121^{\circ} 09.0^{\prime}$ \\
\hline 83.60 & 28 Jan 1999 & $10: 38$ & $33^{\circ} 34.8^{\prime}$ & $120^{\circ} 45.4^{\prime}$ \\
\hline 87.70 & 18 Jan 1999 & $01: 57$ & $32^{\circ} 40.5^{\prime}$ & $121^{\circ} 03.8^{\prime}$ \\
\hline 90.60 & 14 Jan 1999 & $05: 40$ & $32^{\circ} 25.3^{\prime}$ & $119^{\circ} 57.9^{\prime}$ \\
\hline Santa Barbara Basin & 15 Oct 1999 & $13: 42$ & $34^{\circ} 16.6^{\prime}$ & $119^{\circ} 59.6^{\prime}$ \\
\hline Santa Monica Basin & 10 Oct 1999 & $01: 16$ & $33^{\circ} 42.7^{\prime}$ & $118^{\circ} 53.7^{\prime}$ \\
\hline Santa Catalina Basin & 20 Oct 1999 & $17: 03$ & $33^{\circ} 08.0^{\prime}$ & $118^{\circ} 30.0^{\prime}$ \\
\hline Santa Cruz Basin & 14 Oct 1999 & $23: 34$ & $33^{\circ} 43.1^{\prime}$ & $119^{\circ} 27.5^{\prime}$ \\
\hline San Nicolas Basin & 20 Oct 1999 & $10: 38$ & $33^{\circ} 02.5^{\prime}$ & $119^{\circ} 04.4^{\prime}$ \\
\hline 80.60 & 16 Oct 1999 & $04: 44$ & $34^{\circ} 06.7^{\prime}$ & $121^{\circ} 02.5^{\prime}$ \\
\hline 83.60 & 14 Oct 1999 & $04: 40$ & $33^{\circ} 26.1^{\prime}$ & $120^{\circ} 44.6^{\prime}$ \\
\hline 87.70 & 11 Oct 1999 & $04: 59$ & $32^{\circ} 39.4^{\prime}$ & $120^{\circ} 55.8^{\prime}$ \\
\hline $90.60^{*}$ & 19 Oct 1999 & $21: 33$ & $32^{\circ} 28.8^{\prime}$ & $120^{\circ} 18.3^{\prime}$ \\
\hline San Diego Trough & 21 Oct 1999 & $02: 50$ & $32^{\circ} 37.9^{\prime}$ & $117^{\circ} 34.4^{\prime}$ \\
\hline Santa Barbara Basin & 26 Oct 2000 & 05:04 & $34^{\circ} 16.3^{\prime}$ & $120^{\circ} 00.1^{\prime}$ \\
\hline Santa Monica Basin & 19 Oct 2000 & $21: 17$ & $33^{\circ} 41.6^{\prime}$ & $118^{\circ} 52.8^{\prime}$ \\
\hline Santa Catalina Basin & 18 Oct 2000 & $13: 15$ & $33^{\circ} 09.6^{\prime}$ & $118^{\circ} 34.8^{\prime}$ \\
\hline Santa Cruz Basin & 25 Oct 2000 & $13: 47$ & $33^{\circ} 44.2^{\prime}$ & $119^{\circ} 29.7^{\prime}$ \\
\hline San Nicolas Basin & 31 Oct 2000 & $00: 42$ & $33^{\circ} 01.1^{\prime}$ & $119^{\circ} 03.7^{\prime}$ \\
\hline 80.60 & 26 Oct 2000 & $22: 45$ & $34^{\circ} 09.1^{\prime}$ & $121^{\circ} 09.4^{\prime}$ \\
\hline 83.60 & 24 Oct 2000 & $22: 41$ & $33^{\circ} 35.3^{\prime}$ & $120^{\circ} 47.8^{\prime}$ \\
\hline 87.70 & 21 Oct 2000 & $01: 45$ & $32^{\circ} 39.5^{\prime}$ & $121^{\circ} 07.1^{\prime}$ \\
\hline 87.70 & 30 Oct 2000 & $11: 29$ & $32^{\circ} 39.8^{\prime}$ & $121^{\circ} 02.8^{\prime}$ \\
\hline $90.60^{*}$ & 17 Oct 2000 & $14: 37$ & $32^{\circ} 22.1^{\prime}$ & $120^{\circ} 12.1^{\prime}$ \\
\hline San Diego Trough & 12,13 Oct 2000 & $22: 48$ and $02: 42$ & $32^{\circ} 37.5^{\prime}$ & $117^{\circ} 31.0^{\prime}$ \\
\hline San Diego Trough & 31 Oct 2000 & $12: 48$ and $16: 17$ & $32^{\circ} 37.0^{\prime}$ & $117^{\circ} 31.5^{\prime}$ \\
\hline
\end{tabular}

nated from 2 tows on each date (Johnson \& Checkley 2004). The abundance estimate at the San Diego Trough in October 2000 was a mean of the 2 dates sampled. The vertical profile of copepod abundance at Stn 87.70 was concatenated from tows on 2 dates in October 2000 (Table 1).

Samples were quantitatively split after collection using a Folsom splitter, and half was preserved in boratebuffered, 5\% formalin. The abundances of male and female adult (C6) stages, C5s, and fourth copepodid (C4) stages were estimated by enumerating sub-samples of formalin-preserved zooplankton samples. Vertical distributions of dormant C5s were characterized as an estimated median depth, i.e. the mid-depth of the net stratum including the median depth, and a semi-quartile range, i.e. the distance between the median depths of net strata including the first and third depth quartiles. This estimate was subject to high uncertainty associated with the depth stratum size. A 2-way analysis of variance was used to test whether the abundance of dormant C5s was different in basin and non-basin stations and in the 2 yr sampled, and whether there were interactions between sampling year and station type. Student's $t$-tests on arcsine-transformed data were used to test whether the relative abundance of C5s was different in January versus October.

pling represent a range of bottom and sill depths (Table 2). They were sampled from the surface to $50 \mathrm{~m}$ above the bottom, except at the Santa Barbara Basin, which was sampled to $15 \mathrm{~m}$ above the bottom (depth strata sampled replicated Osgood \& Checkley $1997 a, b)$. The non-basin stations chosen for sampling, except the San Diego Trough, were CalCOFI grid stations and are identified by their CalCOFI station numbers (i.e. line number.station number). The starting position of Station (Stn) 90.60 was shifted northwest from its CalCOFI grid location in October of 1999 and 2000, due to shallow bathymetry at CalCOFI Stn 90.60. Non-basin stations were sampled from the surface to either 2000 or $50 \mathrm{~m}$ above the bottom. However, Stn 80.60 was sampled to $1000 \mathrm{~m}$ only, due to the proximity of a seamount to the towing track. In October 2000, the San Diego Trough was sampled on 2 dates, and vertical profiles of copepod abundance were concate-
To identify water mass affiliations of dormant copepods, California Current and California Undercurrent waters were differentiated by their characteristic combinations of temperature and salinity, which are higher at a given density in the undercurrent, reflecting its equatorial source (Lynn \& Simpson 1990). Methods are described in detail in Johnson \& Checkley (2004).

\section{RESULTS}

The dominant developmental stage of Calanus pacificus observed in October of 1999 and 2000 was C5 $(85 \pm 21$ and $94 \pm 8 \%$ of total C4 to C6 abundance; $\bar{x} \pm$ $\mathrm{SD})$. They were present both at the surface and in deep water at all stations sampled in October in both years (Fig. 2). Although the vertical resolution of sam- 
Table 2. Bottom depth at MOCNESS starting positions and basin statistics (Emery 1960)

\begin{tabular}{|lcccc|}
\hline Station & $\begin{array}{c}\text { Bottom } \\
\text { depth (m) }\end{array}$ & $\begin{array}{c}\text { Max. basin } \\
\text { depth }(\mathrm{m})\end{array}$ & $\begin{array}{c}\text { Sill } \\
\text { depth }(\mathrm{m})\end{array}$ & $\begin{array}{c}\text { Basin } \\
\text { volume }\left(\mathrm{km}^{-3}\right)\end{array}$ \\
\hline Santa Barbara Basin & 577 & 627 & 475 & 46 \\
Santa Monica Basin & 910 & 938 & 737 & 208 \\
San Pedro Basin & 890 & 912 & 737 & 79 \\
Santa Catalina Basin & 1290 & 1357 & 982 & 429 \\
Santa Cruz Basin & 1930 & 1966 & 1084 & 875 \\
San Nicolas Basin & 1757 & 1832 & 1106 & 962 \\
San Clemente Basin & 1934 & 2107 & 1816 & 121 \\
CalCOFI 70.60 & 3080 & & & \\
CalCOFI 77.55 & 570 & & & \\
CalCOFI 80.60 & 2300 & & & \\
CalCOFI 83.60 & 1389 & & & \\
CalCOFI 87.70 & 3600 & & & \\
CalCOFI 90.60 & 1040 & & & \\
San Diego Trough & 1180 & & & \\
\hline
\end{tabular}


Concentration (ind. $\mathrm{m}^{-3}$ )

Fig. 2. Calanus pacificus. Vertical distributions of Stage 5 copepodids (C5). Abscissa scale within each panel is indicated by a scale bar. Vertical lines indicate maximum sampling depth. Circles indicate median depth of C5s $<200 \mathrm{~m}$, and horizontal lines indicate semi-quartile ranges. Missing samples are marked with an asterisk. Basins sampled were Santa Barbara Basin (SBB), Santa Monica Basin (SMB), Santa Cruz Basin (SCrB), San Nicholas Basin (SNB), Santa Catalina Basin (SCaB), San Pedro Basin (SPB), and San Clemente Basin (SClB). Non-basin stations sampled included San Diego Trough (SDT) and numbered stations. Strata of high concentration are plotted behind other profiles

pling was coarse, a bimodal distribution of C5s, with very low concentrations between about 100 and $300 \mathrm{~m}$, was observed at most stations (Fig. 2). The percentage of C5s occupying the surface mode was low and variable (1999: $9.6 \pm 14.1 \%$ of total abundance;
2000: $3.1 \pm 4.4 \% ; \bar{x} \pm \mathrm{SD}_{\text {; Fig. }}$ ). Fourth copepodids and adults were observed mainly in the upper $200 \mathrm{~m}$, and C5s were overwhelmingly dominant below $200 \mathrm{~m}(99.4 \pm 0.6 \%$ of individuals below $200 \mathrm{~m}$ in 1999; $99.8 \pm$ $0.3 \%$ in $2000 ; \bar{x} \pm \mathrm{SD}$ ). Dormancy in deep-dwelling C5s was inferred here based on their dominance in deep water. The dominance of post-molt jaw phases among deep-dwelling C5 stages at the San Diego Trough station in October 2000 (Johnson 2004) supports this interpretation. C5s below $200 \mathrm{~m}$ will hereafter be referred to as 'dormant' or 'deep-dwelling.'

Dormant copepods occupied a broad depth range, extending to the deepest strata sampled in both October 1999 and 2000 (Fig. 2); however, their concentrations were low, $<1$ ind. $\mathrm{m}^{-3}$, in strata deeper than $1400 \mathrm{~m}$ (Fig. 2). Between 200 and $1400 \mathrm{~m}$, concentrations of dormant C5s were qualitatively uniform, except at the Santa Barbara Basin. It is not possible to test vertical distributions for uniformity using the Kolmogorov-Smirnov test or $\chi^{2}$ tests, because net sampling violates the assumption of random sampling (Venrick 1986). However, the broad vertical distribution of dormant $\mathrm{C} 5 \mathrm{~s}$ was evident in their high semi-quartile ranges of depth (Fig. 2; October 1999: $464 \pm$ $206 \mathrm{~m}$; October 2000: $358 \pm 186 \mathrm{~m}_{i} \bar{X} \pm$ SD of all stations except the Santa Barbara Basin). In contrast, the vertical distribution of dormant C5s at the Santa Barbara Basin was characterized by a very high concentration in a single stratum in October 1999 and 2000. In October 1999, the highest concentration of $\mathrm{C} 5 \mathrm{~s}$ observed was in the deepest stratum sampled, 509 to $542 \mathrm{~m}$ (Fig. 2). In October 2000, the maximum concentration of $\mathrm{C} 5 \mathrm{~s}$ was just above the sill depth $(475 \mathrm{~m})$, in the 444 to $470 \mathrm{~m}$ depth stratum (Fig. 2). Maximum concentrations of dormant $\mathrm{C} 5 \mathrm{~s}$ were also observed in the deepest strata in the Santa Monica Basin, the second shallowest basin sampled. In the non-basin stations, higher C5 concentrations near the shallow end of the deep mode were more typical (e.g. 87.70 and 90.60 in 1999; 80.60, 87.70, and 90.60 in 2000). 


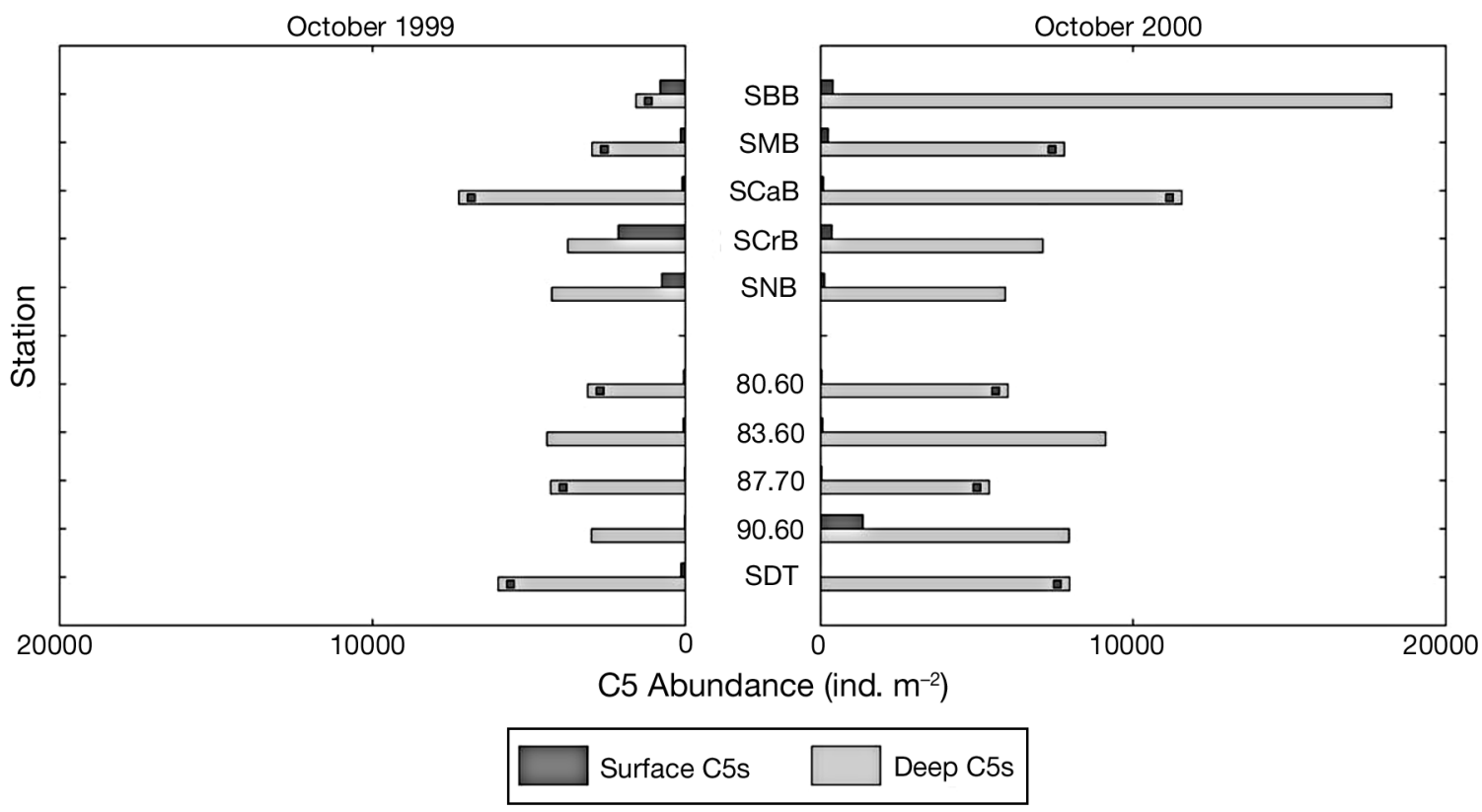

Fig. 3. Calanus pacificus. Abundance of surface (less than ca. $200 \mathrm{~m}$ ) and deep (greater than ca. $200 \mathrm{~m}$ ) C5s in October of 1999 and 2000. Stations at which C5 abundance may be underestimated are labeled with a gray square

The abundance of dormant C5s was compared across station types (basin and non-basin) and years in October of 1999 and 2000 (Fig. 3). The abundance of deep-dwelling C5s was different in the 2 yr (1999: $4.1 \pm$ $1.6 \times 10^{3}$ ind. $\mathrm{m}^{-2} ; 2000: 8.7 \pm 3.8 \times 10^{3}$ ind. $\mathrm{m}^{-2} ; \bar{x} \pm \mathrm{SD}$ ), while there was no significant difference in abundance between the 2 types of stations (basin: $7.0 \pm 4.9 \times$ $10^{3}$ ind. $\mathrm{m}^{-2}$; non-basin: $5.7 \pm 2.1 \times 10^{3}$ ind. $\mathrm{m}^{-2} ; \overline{\mathrm{x}} \pm \mathrm{SD}$ ) and no significant interaction between years and station type (Table 3). This result must be qualified because the abundance of deep-dwelling C5s may be underestimated at several stations (marked with squares in Fig. 3) due to loss of a sample or to limitations in sampling depth. Underestimation is probably highest at stations that have relatively high copepod concentrations in their deepest strata.

The separation of surface and deep C5s observed in October 1999 and 2000 was not distinct in January 1999. In January, deep-dwelling C5s were in shallower water, mainly above $400 \mathrm{~m}$, and the mean semiquartile range for $\mathrm{C} 5 \mathrm{~s}$ below $200 \mathrm{~m}$ was narrower than in October $(43 \pm 53 \mathrm{~m}$; $\bar{X} \pm \mathrm{SD}$ ). Adult stages extended into deeper water (300 to $400 \mathrm{~m}$ ) than in October. C5s made up a lower percentage of the Calanus pacificus enumerated in January 1999 than in October, both in deep water and throughout the water column (Table 4). In January 1999, the abundance of $\mathrm{C} 5 \mathrm{~s}$ throughout the water column was similar among most sta- tions, except the Santa Barbara Basin, where C5 abundance was much greater $\left(5.2 \times 10^{4}\right.$ ind. $\mathrm{m}^{-2}$, compared to $1.9 \pm 2.0 \times 10^{3}$ ind. $\mathrm{m}^{-2} ; \bar{x} \pm \mathrm{SD}$, at other stations).

California Undercurrent water was present at all stations within the continental borderlands of the SCB (i.e. all basin stations and the San Diego Trough) at all dates sampled. Outside the continental borderlands, water properties indicating undercurrent water were weak or absent. In October of 1999 and 2000, dormant C5s were present at a broad range of densities, mainly

Table 3. Two-way ANOVA with replicates $(\mathrm{n}=5)$ comparing the mean abundance of Calanus pacificus C5s at 2 types of stations (basin and open water) in October of 1999 and 2000

\begin{tabular}{|lrrl|}
\hline Source & df & \multicolumn{1}{c|}{$F$} & $\mathrm{p}$ \\
\hline Type & 1 & 2.395 & 0.14 \\
Year & 1 & 14.515 & 0.002 \\
Type $\times$ Year & 1 & 2.217 & 0.16 \\
Error & 16 & & \\
\hline
\end{tabular}

Table 4. Student's t-test comparing developmental stage distributions in January and October. Tests were performed on arcsine-transformed C5/(C4 to C6) abundance proportions. Means are reported as back-transformed values. $\mathrm{n}_{\text {Jan }}$, $\mathrm{n}_{\text {Oct }}$ : number of observations being compared between January and October

\begin{tabular}{|lcccrc|}
\hline Depth category & Jan $\bar{x}$ & Oct $\bar{x}$ & $\mathrm{n}_{\text {Jan }}, \mathrm{n}_{\text {Oct }}$ & $t$ & $\mathrm{p}$ \\
\hline Deep & $76.3 \%$ & $99.7 \%$ & 13,20 & 10.239 & $<0.0001$ \\
Water column & $61.2 \%$ & $92.2 \%$ & 13,20 & 5.201 & $<0.0001$ \\
\hline
\end{tabular}


below the vertical center of the undercurrent at $\sigma_{\theta}=$ 26.5, and their distribution relative to density was not qualitatively different between stations inside and outside the continental borderlands. The mean depth of the undercurrent core was 190 m. In January, dormant C5s were primarily found within the density range of the undercurrent, although low concentrations were also present in deeper water at several stations.

\section{DISCUSSION}

In the 'canonical' view of dormancy in oceanic copepods, dormant stages accumulate during part of the year until all or nearly all of the population is represented by dormant individuals. However, deviations from this pattern occur in many regions, particularly in populations living at the extremes of their geographical range (Conover 1988). Although part of the Calanus pacificus population remains active year-round in the waters off Southern California (Fleminger 1985), seasonal time-series studies in the San Diego Trough and Santa Barbara Basin have found that nearly the entire population, as represented by late copepodid stages, is dormant in October (Osgood \& Checkley 1997b, Johnson \& Checkley 2004). The present study suggests that this pattern holds throughout the region off Southern California, as the great majority of late copepodid stages were represented by C5s in deep water in October. Copepod dormancy is usually associated with regions of high seasonal environmental variability (Dahms 1995); however, seasonal variability off Southern California is relatively weak, and interannual variability is strong (Mullin 1986). Nevertheless, most of the C. pacificus population appears to become dormant for part of the year in this region, similar to C. pacificus near the northern end of its range in Dabob Bay, Washington, USA (Osgood \& Frost 1994).

At the San Diego Trough, the distribution of dormant C5s deepens and broadens from June until October, and then shoals and narrows from October through January (Johnson \& Checkley 2004). Similar seasonal shifts in the vertical distribution of dormant copepods, from a deep, broad distribution in October to a shallower, narrow distribution in January, were also observed in the present study throughout the region off Southern California. The depths occupied by dormant C5s in October remove most of the dormant population from equatorward transport in the California Current, which extends to depths of about $300 \mathrm{~m}$ outside of the SCB (Lynn \& Simpson 1987), and expose shallower C5s in the SCB to poleward transport in the California Undercurrent. Undercurrent flow is strong in the summer and fall, the season of dormancy, and although the core of the undercurrent is narrow, lower- velocity poleward flow in the California Undercurrent can extend 100 to $150 \mathrm{~km}$ offshore (Lynn \& Simpson 1990). The broad depth distribution of C5s in October may reflect a trade-off between the benefit of poleward transport for population retention and the cost of higher metabolic and visual predation rates in the warm $\left(8\right.$ to $\left.9^{\circ} \mathrm{C}\right)$, relatively shallow undercurrent. Residence at the depth of the California Undercurrent may also increase the risk of offshore transport in eddies, which would remove copepods from productive coastal upwelling zones (Simpson \& Lynn 1990, Chereskin et al. 2000, Collins et al. 2000). Below the undercurrent, mean velocities are close to zero (Lynn \& Simpson 1990, Hickey 1992, Collins et al. 2000); therefore residence in deeper water would have a similar effect on retention of Calanus pacificus in the California Current System as residence in deep basins.

The similarity in the vertical distributions of dormant C5s across stations in a given cruise or month, regardless of the presence of the undercurrent, suggests similar depth-keeping behavior across the region. The shift from deeper to shallower depths between October and January implies that copepods probably do not track depths where they are neutrally buoyant, as set by body composition and, particularly, wax ester content (Visser \& Jónasdóttir 1999), since their depth distribution shoals during late dormancy when their wax ester content is expected to decrease resulting in increased density. However, alternate behaviors that copepods may use to control their depth during dormancy remain to be determined.

No difference was detected in the abundance of dormant Calanus pacificus in basins and deep, non-basin stations in October of 1999 and 2000, perhaps because near-bottom copepod abundance was not estimated. A combination of deeper net sampling and near-bottom sampling with alternate sampling gear, such as video and water-collection gear mounted on a remotely operated vehicle, would be required to resolve this question (Hirche et al. 2006). Sameoto \& Herman (1990) and Osgood \& Checkley (1997b) suggested that dormant copepods become aggregated in deep basins if they descend from water advected over the basin. This aggregation mechanism requires that the depths of dormant copepods be greater than the basin sill depth. In October of 1999 and 2000, most dormant C5s in open water off Southern California were observed between 200 and 1400 m. At the Santa Barbara Basin, $77 \%$ of this depth range is below the sill depth (Table 2), the highest percentage of any basin examined. At the Santa Monica Basin, which shares with San Pedro Basin, the second shallowest sill depth of the SCB basins (Emery 1960), 55\% of the depth range of dormant copepods is below the sill depth, and at Santa Catalina, Santa Cruz, and San Nicolas Basins, a 
third or less of this range is below the sill depth. These estimates are seasonal maxima, as vertical distributions of dormant C. pacificus are deepest in October in this region (Johnson \& Checkley 2004). Thus, most basins in this region have relatively little potential to trap dormant $C$. pacificus.

The difference between dormant C5 mean abundance on the 2 October dates sampled is consistent with strong interannual variability in Calanus pacificus abundance at the surface in this region (Mullin 1998, Rebstock 2002). The difference in abundance between the $2 \mathrm{yr}$, approximately a factor of 2 , may represent either a difference in the maximum seasonal abundance of dormant $C$. pacificus or in the timing of the seasonal abundance peak of dormant copepodids. The high abundance of the dormant phase of the population in deep water in fall implies that seasonal variation in C. pacificus abundance is overestimated in samples collected by the CalCOFI program, a long-term monitoring program that has sampled zooplankton in the upper 140 or $210 \mathrm{~m}$ of the water column since 1951 . C. pacificus is a biomass dominant in the California Current System, and therefore estimates of seasonal variation in zooplankton biomass must also be overestimated. Vertical migration associated with dormancy, as well as the possible changes in its dormancy timing, must be considered in studies of long-term variability in both Calanus abundance and zooplankton biomass that use the CalCOFI data (e.g. Roemmich \& McGowan 1995, Mullin 1998, Rebstock 2002).

Comparison of dormant C5 abundance in the Santa Barbara Basin with previous studies indicates even higher interannual variability than implied by the present study (Alldredge et al. 1984, Osgood \& Checkley 1997b). High interannual variability in dormant C5s at the Santa Barbara Basin may reflect either region-wide levels of variability or processes unique to the Santa Barbara Basin. Interannual differences in the seasonal dynamics of dormant Calanus pacificus in the basin (Osgood \& Checkley 1997b, present study) suggest that the latter may be true. In addition to the Santa Barbara Basin's unique, shallow morphology, it is also subject to relatively unpredictable flushing events and to climatically induced shifts in circulation (Bograd et al. 2002, Winant et al. 2003). Oxygen concentrations in the deep Santa Barbara Basin, an indicator of basin flushing, were different in October 1999 and 2000. In 2000 , oxygen concentrations were very low, $0.01 \mathrm{ml} \mathrm{l}^{-1}$ or less, below $500 \mathrm{~m}$ (Scripps Institution of Oceanography 2001), and copepods were absent from the deepest strata sampled. In 1999, elevated oxygen concentrations in deep water $\left(0.16 \mathrm{ml} \mathrm{l}^{-1}\right.$ at $\left.569 \mathrm{~m}\right)$ indicated that the basin had recently been flushed (Scripps Institution of Oceanography 2000), and maximal concentrations of C5s were observed in the deepest MOCNESS stratum (513 to $546 \mathrm{~m}$ ). These observations support Osgood \& Checkley's (1997b) hypothesis that dormant copepods may be forced out of the deep Santa Barbara Basin by very low oxygen concentrations; if they move above the sill depth, they would be dispersed from the basin. Irregular basin flushing and resulting shifts in deep-water conditions may lead to significant interannual differences in the abundance of $C$. pacificus that can be retained in the Santa Barbara Basin throughout the dormant season.

\section{CONCLUSION}

Osgood \& Checkley (1997a) proposed that the Santa Barbara Basin could serve as a significant point source of Calanus pacificus emerging from dormancy and seeding population growth in surface waters of the SCB. The results of the present study suggest that, with the exception of the Santa Barbara Basin, deep basins of the SCB have little effect on the concentration and abundance of the dormant copepods residing in them, and that seasonal dynamics of dormant copepods are similar in basins and in deep water outside of basins. Migration to deep water associated with dormancy moves copepods out of equatorward flow at the surface into low-velocity water either inside or outside basins or into poleward flow in the California Undercurrent. Dormant C. pacificus are widespread and abundant in deep water throughout the region sampled; therefore, non-point sources of dormant C. pacificus are probably numerically dominant in seeding surface waters in the California Current System.

Acknowledgements. This research was supported by the Office of Naval Research through Contract N00014-11-10172 to D. M. Checkley. C.L.J. was also supported by a National Defense Science and Engineering Graduate Fellowship and by a scholarship from the Achievement Rewards for College Scientists Foundation, San Diego Chapter. The CalCOFI program generously provided ship time, and CalCOFI technicians provided invaluable assistance and expertise. The MOCNESS was loaned by Southwest Fisheries Science Center, and expert training, advice, and assistance were provided by D. Griffith, R. Dotson, and A. Hays. I am grateful to the captains, crew, and resident technicians of the RVs 'Revelle' and 'New Horizon' and to volunteers K. Curtis, J. Low, V. Massoud, and S. Miller for assistance with sample collection at sea. J. Gendron assisted with copepod enumeration. CalCOFI and SWFSC provided hydrographic data. The manuscript was improved by comments made by D. M. Checkley, M. D. Ohman, and 3 anonymous reviewers.

\section{LITERATURE CITED}

Alldredge AL, Robison BH, Fleminger A, Torres JJ, King JM, Hamner WM (1984) Direct sampling and in situ observation of a persistent copepod aggregation in the meso- 
pelagic zone of the Santa Barbara Basin USA. Mar Biol 80: 75-82

Bagøien E, Kaartvedt S, Øverås S (2000) Seasonal vertical migrations of Calanus spp. in Oslofjorden. Sarsia 85:299-311

Bograd SJ, Schwing FB, Castro CG, Timothy DA (2002) Bottom water renewal in the Santa Barbara Basin. J Geophys Res 107:3216

Chereskin TK, Morris MY, Niiler PP, Kosro PM, Smith RL, Ramp SR, Collins CA, Musgrave DL (2000) Spatial and temporal characteristics of the mesoscale circulation of the California Current from eddy-resolving moored and shipboard measurements. J Geophys Res 105:1245-1269

Collins CA, Garfield N, Rago TA, Rischmiller FW, Carter E (2000) Mean structure of the inshore countercurrent and California undercurrent off Point Sur, California. DeepSea Res II 47:765-782

Conover RJ (1988) Comparative life histories in the genera Calanus and Neocalanus in high latitudes of the northern hemisphere. Hydrobiologia 167/168:127-142

Dahms HU (1995) Dormancy in the Copepoda - an overview. Hydrobiologia 306:199-211

Eiane K, Aksnes DL, Ohman MD (1998) Advection and zooplankton fitness. Sarsia 83:87-93

Emery KO (1960) The sea off Southern California, a modern habitat of petroleum. John Wiley, New York

Fleminger A (1966) Submergence of certain California Current copepods in a region of advection with Central Pacific Water. In: Proceedings of the 2nd International Oceanographic Congress, Moscow, no. 127-SIIb, p 118-119 (Abstract)

Fleminger A (1985) Dimorphism and possible sex change in copepods of the family Calanidae. Mar Biol 88:273-294

Hickey BM (1992) Circulation over the Santa Monica-San Pedro Basin and shelf. Prog Oceanogr 30:37-115

Hirche HJ (1996) Diapause in the marine copepod, Calanus finmarchicus - a review. Ophelia 44:129-143

Hirche HJ, Muyakshin S, Klages M, Auel H (2006) Aggregation of the Arctic copepod Calanus hyperboreus over the ocean floor of the Greenland Sea. Deep-Sea Res I 53: $310-320$

John HC, Mittelstaedt E, Schulz K (1998) The boundary circulation along the European continental slope as transport vehicle for two calanid copepods in the Bay of Biscay. Oceanol Acta 21:307-318

Johnson CL (2004) Seasonal variation in the molt status of an oceanic copepod. Prog Oceanogr 62:15-32

Johnson CL, Checkley Jr DM (2004) Vertical distribution of diapausing Calanus pacificus (Copepoda) and implications for transport in the California Undercurrent. Prog Oceanogr 62:1-13

Longhurst AR (1967) Vertical distribution of zooplankton in relation to the eastern Pacific oxygen minimum. Deep-Sea Res 14:51-63

Lynn RJ, Simpson JJ (1987) The California Current system: the seasonal variability of its physical characteristics. J Geophys Res 92:12947-12966

Editorial responsibility: Kenneth Sherman (Contributing Editor), Narragansett, Rhode Island, USA
Lynn RJ, Simpson JJ (1990) The flow of the undercurrent over the California borderland off Southern California. J Geophys Res 95:12995-13008

Mullin MM (1986) Spatial and temporal scales and patterns. In: Eppley RW (ed) Plankton dynamics of the Southern California Bight, Vol 15. Springer-Verlag, Berlin, p 216-273

Mullin MM (1998) Interannual and interdecadal variation in California Current zooplankton: Calanus in the late 1950s and early 1990s. Global Change Biol 4:115-119

Ohman MD, Drits AV, Clarke ME, Plourde S (1998) Differential dormancy of co-occurring copepods. Deep-Sea Res II 45:1709-1740

Osgood KE, Checkley DM Jr (1997a) Observations of a deep aggregation of Calanus pacificus in the Santa Barbara Basin. Limnol Oceanogr 42:997-1001

Osgood KE, Checkley DM Jr (1997b) Seasonal variations in a deep aggregation of Calanus pacificus in the Santa Barbara Basin. Mar Ecol Prog Ser 148:59-69

Osgood KE, Frost BW (1994) Comparative life histories of three species of planktonic calanoid copepods in Dabob Bay, Washington. Mar Biol 118:627-636

Osgood KE, Frost BW (1996) Effects of advection on the seasonal abundance patterns of three species of planktonic calanoid copepods in Dabob Bay, Washington. Cont Shelf Res 16:1225-1243

Peterson W (1998) Life cycle strategies of copepods in upwelling zones. J Mar Res 15:313-326

Rebstock GA (2002) Climatic regime shifts and decadal-scale variability in calanoid copepod populations off southern California. Global Change Biol 8:71-89

Roemmich D, McGowan J (1995) Climatic warming and the decline of zooplankton in the California Current. Science 267:1324-1326

Sameoto DD, Herman AW (1990) Life cycle and distribution of Calanus finmarchicus in deep basins on the Nova Scotia shelf and seasonal changes in Calanus spp. Mar Ecol Prog Ser 66:225-237

Scripps Institution of Oceanography (2000) Physical, chemical, and biological data, CalCOFI cruises 9908, 9910. SIO Ref. 00-10, Scripps Institution of Oceanography, La Jolla

Scripps Institution of Oceanography (2001) Physical, chemical, and biological data, CalCOFI cruises 0007, 0010. SIO Ref. 01-5, Scripps Institution of Oceanography, La Jolla

Simpson JJ, Lynn RL (1990) A mesoscale eddy dipole in the offshore California Current. J Geophys Res 95: 13009-13022

Venrick EL (1986) The Smirnov statistic: an incorrect test for vertical distribution patterns. Deep-Sea Res 33:1275-1277

Visser AW, Jónasdóttir SH (1999) Lipids, buoyancy and the seasonal vertical migration of Calanus finmarchicus. Fish Oceanogr 8(Suppl 1):100-106

Winant CD, Dever EP, Hendershott MC (2003) Characteristic patterns of shelf circulation at the boundary between central and southern California. J Geophys Res 108:3021

Submitted: April 8, 2005; Accepted: October 2, 2006

Proofs received from author(s): April 6, 2007 